\title{
Strain specific differences in ribosomal DNA from the ectomycorrhizal fungi Laccaria bicolor (Maire) Orton and Laccaria laccata (Scop ex Fr) Br
}

\author{
F Martin 1*, M Zaiou 1, F Le Tacon 1, P Rygiewicz 2 \\ 1 INRA, Laboratoire de Microbiologie Forestières, Champenoux 54280 Seichamps, France; \\ 2 US Environmental Protection Agency, Environmental Research Laboratory, \\ 200 SW 35 th St, Corvallis, OR 97333, USA
}

(Received 6 August 1990; accepted 24 January 1991)

\begin{abstract}
Summary - The restriction fragment length polymorphism patterns of the ribosomal RNA genes of 14 isolates belonging to various ectomycorrhizal fungus species including the related basidiomycetous ectomycorrhizal fungi Laccaria laccata (Scop ex $\mathrm{Fr}$ ) $\mathrm{Br}$ and Laccaria bicolor (Maire) Orton have been determined. The isolates were obtained from various geographical sources in France, the United Kingdom and North America. Total DNA of vegetative mycelium was cleaved with a series of restriction enzymes, electrophoretically separated and probed with radiolabelled rDNA gene from Coprinus cinereus (Schaeff: Fr) SF Gray. Results indicate that isolates belonging to different species had different restriction enzyme sites in the rDNA. Although distinct patterns were observed within species, a core of common bands could be discerned within each species. Since various patterns were observed within $L$ bicolor and $L$ laccata, rRNA gene restriction patterns may have epidemiological as well as taxonomic interest.
\end{abstract}

Laccaria bicolor / Laccaria laccata / restriction fragment length polymorphism / RFLP / ribosomal DNA / taxonomy / epidemiology

Résumé - Étude du polymorphisme de l'ADN ribosomal chez différentes souches de champignons ectomycorhiziens Laccaria bicolor et Laccaria laccata. Afin de caractériser la diversité génétique au sein des champignons ectomycorhiziens appartenant aux espèces Laccaria bicolor et L laccata, une étude du polymorphisme de l'ADN ribosomal (ADNr) de 14 souches appartenant à plusieurs espèces et de provenances géographiques variées a été entreprise. Dans un premier temps, nous avons développé une méthode d'extraction de l'ADN total du mycélium végétatif simple et rapide. Les régions intergéniques de l'ADNr des champignons présentant des variations importantes à la fois au niveau du nombre de sites de restriction des endonucléases et au niveau de la taille des séquences, une analyse du polymorphisme de longueur des fragments de restriction (RFLP) a été conduite sur l'ADN total de ces champignons mycorhiziens. II apparaît que le polymorphisme de longueur des fragments de restriction est très important entre des genres différents (fig $1 A$ ), modérés entre espèces d'un même genre (figs $2 A$ et $B$ ) et restreint avec les isolats d'une même espèce (figs $2 A$ et $B$ ). En général, on observe un bonne conservation du nombre de sites de restriction au niveau du gène de l'ADNr des Laccaires. Les fragments de restriction EcoRI de 1.45, 8.0, et $9.4 \mathrm{kpb}$ se rencontrent chez la plupart des souches de Laccaria que nous avons analysées (tableau II). La comparaison des profils de restriction $E c o R /$ des souches de $L$ bicolor et $L$ laccata permet l'attribution aisée d'une souche à l'une ou l'autre de ces deux espèces. De plus, le polymorphisme des fragments de restriction est suffisant pour distinguer les souches de provenances géographiques différentes (figs $2 A$ et $B$ ).

\footnotetext{
* Correspondence and reprints
} 
II est particulièrement intéressant de noter que le profil de restriction de L laccata S238 que nous avons obtenu est similaire à celui des isolats américains de L bicolor CRBF581 et CRBF569. Ces résultats confirment ceux publiés par Armstrong et al (1989) et conduisent à reclasser la souche américaine L laccata S238 dans l'espèce bicolor.

En conclusion, l'étude du polymorphisme des fragments de restriction de l'ADNr des champignons ectomycorhiziens nous a permis de : 1) montrer que le gène codant pour les ARNr de Laccaria présente une homologie élevée avec le gène de Coprinus cinereus confirmant une conservation importante de I'ADNr au sein des Agaricales; 2) démontrer qu'il existe un polymorphisme des fragments de restriction de l'ADNr au sein des isolats des différentes espèces analysées; et 3) discriminer un certain nombre de souches appartenant aux espèces Laccaria bicolor et $L$ laccata. La RFLP de l'ADNr peut donc s'appliquer avec succès à l'étude des divergences génétiques et à l'identification de champignons ectomycorhiziens. L'amplification préalable de l'ADNr à l'aide de la PCR (Polymerase Chain Reaction), en évitant l'emploi de radioisotopes, devrait conduire à une simplification considérable de l'analyse du polymorphisme des fragments de restriction.

Laccaria bicolor / Laccaria laccata / polymorphisme des fragments de restriction / RFLP / ADN ribosomal / taxonomie / epidémiologie

\section{INTRODUCTION}

Laccaria laccata (Scop ex $\mathrm{Fr}$ ) $\mathrm{Br}$ and $\angle b i$ color (Maire) Orton species are ectomycorrhizal fungi belonging to the Tricholomataceae. Despite many common properties, there is a high degree of variation in morphological, physiological, and biochemical characteristics among species as revealed by growth behaviour, mycorrhizal competence (Kropp et al, 1986; Kropp and Fortin, 1988; Wong et al, 1989) and electrophoretic polypeptide patterns (Hilbert and Martin, unpublished data). Thus, it appears that distinct subgroups of $L$ laccata and $L$ bicolor are present, but the biological status of these subgroups and their interrelationships are poorly known. However, it is important to accurately differentiate these subgroups because, within isolates of $L$ laccata and $L$ bicolor, some are more efficient than others at increasing tree growth under nursery and field conditions (Le Tacon et al, 1988).

The increased incidence of sylvicultural use of ectomycorrhizal species has stimulated interest in the use of epidemiological markers to fingerprint and compare isolates. Morphological methods rely upon the anatomy of fruitbodies and spores for accurate identifications. While Laccaria B and $\mathrm{Br}$ (Agaricales) is well described, several taxonomic and nomenclatural problems have persisted within the genus (Mueller and Vellinga, 1986). An alternative identification method which would be more rapid and specific is therefore desirable. Biochemical approaches, such as isoenzyme patterns, 2-dimensional gel electrophoresis and immunochemical techniques are currently under investigation. Recent studies have demonstrated the use of relatively large DNA fragments complementary to sequences of the $17 \mathrm{~S}$ and 25S ribosomal RNA molecule as group-specific probes in hybridization tests using fungi (Wu et al, 1983; Specht et al, 1984; Klassen et al, 1987; Hintz et al, 1989).

The use of RFLP (restriction fragment length polymorphism) analysis of DNA as an aid in ectomycorrhizal fungus taxonomy has been recently reported (Amstrong et al, 1989; Rogers et al, 1989; Gardes et al, 1990, 1991). These studies demonstrated the potential usefulness of the RNA gene restriction pattern as a taxonomic tool and that restriction enzyme patterns of the rDNA from many ectomycorrhizal fungi in- 
cluding Laccaria species were different. We report here on rDNA polymorphisms among $L$ bicolor and $L$ laccata isolates from various geographical sources in France, the United Kingdom and North America. In addition, a rapid micropreparation method to extract high molecular weight DNA from small amounts of ectomycorrhizal mycelia is described.

\section{MATERIALS AND METHODS}

\section{Strains and culture conditions}

Isolates were obtained from various geographical sites in France, the United Kingdom and North America (table 1). The identification of sporocarps collected in France was confirmed by Prof Lamoure at the University Claude Bernard (Lyon, France) and those collected in North America by $G$ Mueller (Department of Botany, Field Museum of Natural History, Chicago, USA). Media and methods for the routine culturing of all isolates were as described by Martin et al (1990).

\section{Isolation of DNA}

Whole-cell DNA from vegetative mycelium was prepared as follows: fungal mycelium from a 250-ml culture was collected in a sieve and dried in several portions onto filter papers (Whatman No1, in a Büchner funnel connected to a water pump). The resulting "cakes" were peeled off, frozen in liquid nitrogen and lyophilized overnight. About $50 \mathrm{mg}$ of the lyophilized material was ground with a mortar and pestle until it had the consistency of fine sand. Ground tissue was suspended in $500 \mu \mathrm{l} 20 \mathrm{mM}$ Tris- $\mathrm{HCl}$ pH 8.0, $50 \mathrm{mM}$ EDTA pH 8.0, $250 \mathrm{mM} \mathrm{NaCl}$, $0.5 \%$ SDS and $0.1 \mathrm{mg}$ proteinase $\mathrm{K}$ for $4 \mathrm{~h}$ at 55 ${ }^{\circ} \mathrm{C}$. The fungal suspension was centrifuged at $32000 \mathrm{~g}$ for $30 \mathrm{~min}$ at $4^{\circ} \mathrm{C}$ to pellet the cellular debris. Proteins in the supernatant were denatured and removed by sequential extractions with $500 \mu \mathrm{l}$ Tris-saturated phenol-chloroform- isoamyl alcohol $(24 / 24 / 2, v / v / v)$ and chloroformisoamyl alcohol (24/1, v/v) (Maniatis ef al, 1982). The phases were separated by centrifugation for $15 \mathrm{~min}$ at $7500 \mathrm{~g}$. The aqueous phase was taken off carefully and was incubated with 10 units RNAse A ( $5 \mathrm{mg} / \mathrm{ml}$, Sigma Type IIIA, preincubated for $15 \mathrm{~min}$ at $65^{\circ} \mathrm{C}$ in $50 \mathrm{mM} \mathrm{Na}$ acetate $\mathrm{pH}$ 6.5 to denature DNAase activity) for $2 \mathrm{~h}$ at 37 ${ }^{\circ} \mathrm{C}$. The solution was then mixed with $50 \mu \mathrm{l} 3 \mathrm{M}$ $\mathrm{Na}$ acetate and $1.5 \mathrm{ml}$ cold absolute ethanol, followed by gentle mixing. DNA was then pelleted by centri-fugation at $7500 \mathrm{~g}$ for $10 \mathrm{~min}$, washed with $70 \%(v / v)$ ethanol, pelleted again, and dried in a vacuum dessicator for $5 \mathrm{~min}$. Finally, the DNA pellet was rehydrated in 20 to $200 \mu \mathrm{l}$ of 10 $\mathrm{mM}$ Tris- $\mathrm{HCl}$ buffer $(\mathrm{pH} 8.0$ ) containing $1 \mathrm{mM}$ EDTA and stored at $-20^{\circ} \mathrm{C}$ until use.

\section{Restriction endonuclease digestion and agarose gel electrophoresis}

One to $2 \mu \mathrm{g}$ DNA were digested overnight with 5-10 units of various restriction enzymes (BamHI, EcoRl, Pvull, Hindll) (Pharmacia Fine Chemicals, St Quentin/Yvelines, France) or Gibco-BRL (Cergy Pontoise, France) according to the manufacturers' instructions. The restriction fragments were size-fractionated on a $5 \times 10 \mathrm{~cm}$ $1.0 \%$ agarose gel in TBE $(89 \mathrm{mM}$ Tris- $\mathrm{HCl} ; 89$ $\mathrm{mM}$ boric acid; $2 \mathrm{mM}$ EDTA, $\mathrm{pH} 8.0$ ) as described by Maniatis et al (1982). The DNA was electrophoresed at $75 \mathrm{~mA}$ for $1 \mathrm{~h}$. Bacteriophage $\lambda$, digested with Hindll, was used as a size standard.

\section{Southern blotting and hybridization}

After electrophoresis, agarose gels were sequentially soaked in $0.25 \mathrm{M} \mathrm{HCl}$ for $5 \mathrm{~min}$, distilled water for $15 \mathrm{~min}$, twice in $1.5 \mathrm{M} \mathrm{NaCl}, 0.5$ $\mathrm{M} \mathrm{NaOH}$ for $30 \mathrm{~min}$ and twice in $1.0 \mathrm{M}$ Tris $-\mathrm{HCl}$ (pH 8.0), $1.5 \mathrm{M} \mathrm{NaCl}$ for $30 \mathrm{~min}$. Southern blotting (Southern, 1975) was carried out on $\mathrm{Hy}$ bond- $\mathrm{N}$ nylon membrane (Amersham France, Les Ulis) according to Maniatis et al (1982). The blotted DNA was fixed by UV irradiation at 312 $\mathrm{nm}$ for $3 \mathrm{~min}$. Plasmid pCc1 (courtesy of P Pukkila, University of North Carolina) encoding one complete repeat of the rDNA from Coprinus ci- 


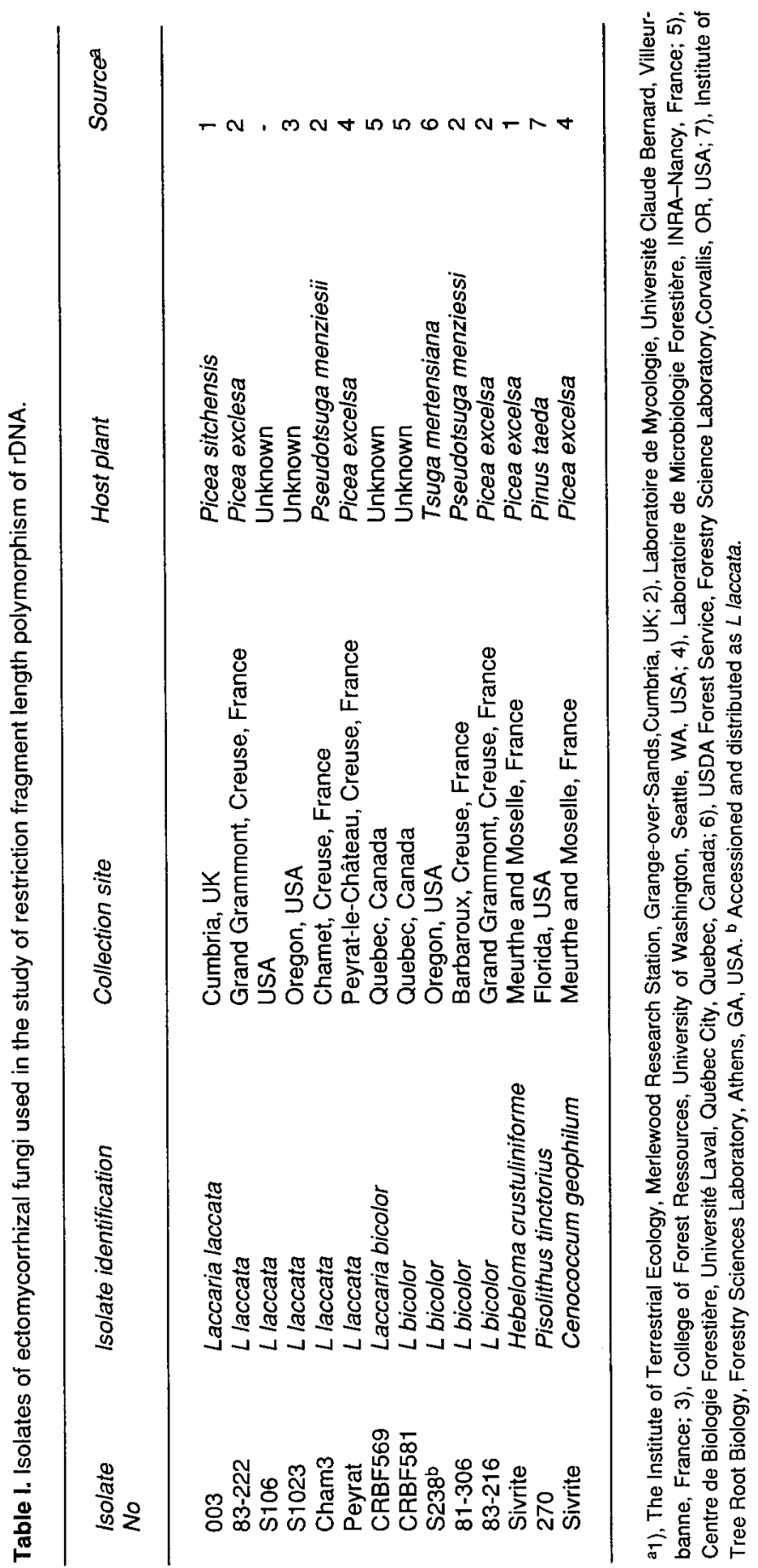


nereus (restriction map in Cassidy et al, 1984), was labelled with $\left[\alpha-{ }^{32} \mathrm{P}\right] \mathrm{dCTP}(3000 \mathrm{Ci} / \mathrm{mol})$ using a nick-translation kit (Amersham France, Les Ulis) according to the manufacturers' instructions. The prehybridization, hybridization and washing steps were performed under high stringency conditions as described previously (Armstrong et al, 1989). The blots were dried for 30 min at $60^{\circ} \mathrm{C}$ in the Biorad Model $543 \mathrm{gel}$ dryer and exposed to Hyperfilm-MP (Amersham France, Les Ulis) at $-70^{\circ} \mathrm{C}$ for $24 \mathrm{~h}$ to several days.

\section{RESULTS}

From $50 \mathrm{mg}$ lyophilized fungal tissue 25$40 \mu \mathrm{g}$ of high molecular weight DNA were purified depending on the isolate. The DNA averaged from 25-30 kilobases (kb) in length with little degradation evident (data not shown). Restriction patterns of the purified DNA were obtained from all but one fungus (Pisolithus tinctorius Coker and Couch). It is significant to note that the DNA purification method used in the present study was rapid and relatively inexpensive. The time and cost of isopycnic $\mathrm{CsCl}$ ultracentrifugation were not necessary.

Ribosomal RNA genes are conserved (Garber et al, 1988) and have been extensively used as probes for rDNA of phylogenetically diverse fungi (Reader and Broda, 1984; Specht et al, 1984; Klich and Mullaney, 1987; Garber et al, 1988; Hintz et al, 1989; Laaser et al, 1989) including ectomycorrhizal species (Armstrong et al, 1989; Rogers et al, 1989). Therefore, we used the rDNA probe of the basidiomycete Coprinus cinereus to survey the extent of interstrain and interspecies variation in the rDNA of 14 isolates from 5 species of ectomycorrhizal fungi. Labelled-rDNA of Coprinus cinereus was hybridized to Southern transfers of restricted DNA of the ectomycorrhizal fungi Cenococcum geo- philum $\mathrm{Fr}$, Hebeloma crustuliniforme (Bull ex Pt Am) Q, Pisolithus tinctorius, Laccaria laccata (Scop ex $\mathrm{Fr}$ ) Bk-Br and $L$ bicolor (Maire) Orton. Hybridization patterns confirmed that $C$ cinereus rDNA had strong sequence homology with rDNA of the investigated mycorrhizal fungi (fig 1).

The rDNA of these species was restricted with the endonucleases Hindll, Pvull, and EcoRI. Of the 4 species assayed for their EcoRI rDNA hybridization patterns, $C$ geophilum, $L$ laccata, $L$ bicolor and $P$ tinctorius exhibited patterns that appeared characteristic for that genera (fig 1A). Hindll yielded 2 homologous bands with Laccaria bicolor and L laccata isolates (fig 1B) and 1 with the other species (data not shown). Pvull gave rise to 1 band for $C$ geophilum, L bicolor, Paxillus involutus, and Pisolithus tinctorius, and 4 bands for $H$ crustuliniforme (data not shown). Hindll

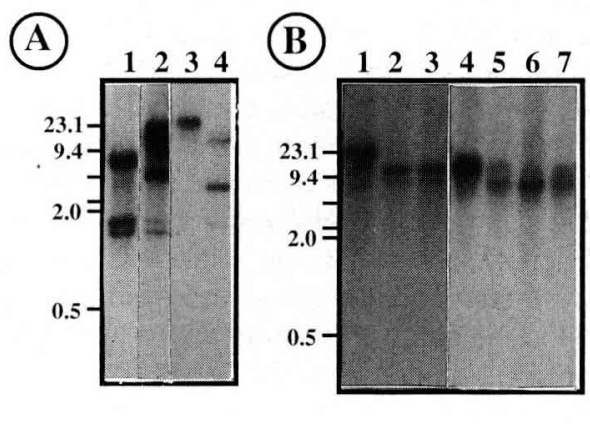

Fig 1. Autoradiogram of EcoRl-(A) and Hindll(B) digests of DNA from ectomycorrhizal fungi, separated by electrophoresis and hybridized with ${ }^{32}$ p-labelled rDNA (plasmid pCc1). A), lane 1, Laccaria bicolor 81-306; lane 2, Laccaria laccata S106; lane 3, Pisolithus tinctorius 270; lane 4, Cenococcum geophilum Sivrite. B) lane 1, L bicolor 81-306; lane 2, $L$ bicolor CRBF581; lane 3, $L$ bicolor CRBF569; lane 4, L laccata 83-222; lane 5, L laccata Peyrat; lane 6, L bicolor S238 (accessioned and distributed as $L$ laccata S238); lane 7, L laccata Cham3. To the left a molecular mass scale as determined by the position of Hindll-cut $\lambda$ DNA standard. 
and Pvull were thus not sufficient to discriminate among the fungal genera. However, as pointed out previously (Armstrong et al, 1989), it was possible to make genus-specific identifications when the RFLPs produced by all enzymes were compared collectively.

EcoRI rDNA hybridization patterns were employed for investigating the extent of interspecific and intraspecific variations in the rDNA of 12 isolates of $L$ laccata and $L$ bicolor from different geographical locations. Isolates belonging to different $\mathrm{Lac}$ caria species did not share the same pattern (fig 2). Each species, however, could be characterized by a core of common rDNA gene restriction fragments which constituted a species-specific pattern. Most $L$ laccata isolates had major EcoRl fragments at $1.45,4.0$ and $8.0 \mathrm{~kb}$ (fig 2A) whereas the $L$ bicolor isolates had major bands at $1.45,2.0$ and $8.0 \mathrm{~kb}$ (fig 1 A, lane 2 and $2 B$ ). The $4.0-k b$ fragment appeared characteristic for $L$ laccata isolates, whereas the $2.0 \mathrm{~kb}$ fragment could be detected in some isolates of both species. However, in spite of these restriction polymorphisms, the sizes of the rDNAs were similar. When fragment sizes of the digested rDNAs were summed, the gene was estimated to be in the same size range as those of other fungi, ie 11-14 kb (Garber et al, 1988).

As expected, the coding regions appear to be highly conserved among the two species, while the spacer regions exhibited larger diversity. The $1.45 \mathrm{~kb} E c o R l$ fragment including the $5^{\prime}$ end of the $25 \mathrm{~S}$ rDNA gene (fig 3; see also Garber et al, 1988) was present in all Laccaria isolates examined (fig 2). The 1.70-kb fragment containing over half of the $25 \mathrm{~S}$ rDNA gene was observed in isolates 81306 and 83216 of $L$ bicolor and in isolates Cham3, 83222 and 003 of $L$ laccata. By contrast, a band at $2.0 \mathrm{~kb}$ was observed in isolates devoid of the $1.7-\mathrm{kb}$ fragment. The band presum- ably results from a $0.3-\mathrm{kb}$ insertion into the $25 S$ rDNA as observed in several fungal species (eg, Hebeloma mesophaeum, Galerina autumnalis) (Rogers et al, 1989). In addition, there are 2 bands visible at $3.8 \mathrm{~kb}$ and $4.0 \mathrm{~kb}$ in EcoRl-restricted DNA of
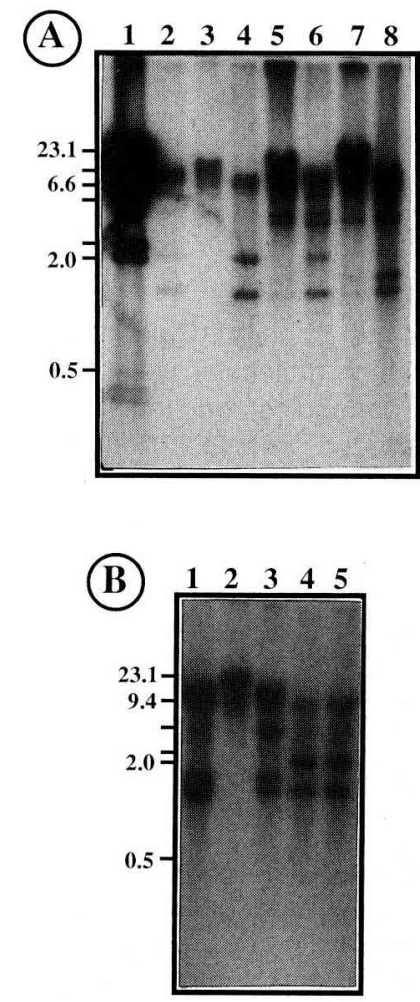

Fig 2. Autoradiogram of EcoRI-digests of DNA from Laccaria laccata $(A)$ and $L$ bicolor $(B)$ isolates, separated by electrophoresis and probed with ${ }^{32}$ P-labelled rDNA (plasmid pCc1). A), lane 1 , molecular mass standard (Hindll-digested $\lambda$ DNA), lane 2, Laccaria laccata S1023; lane 3, L laccata S106; lane 4, L bicolor S238 (accessioned and distributed as $L$ laccata S238); lane 5, $L$ laccata 003; lane 6, L laccata Peyrat; lane 7, L laccata 83-222; lane 8, L laccata Cham3; B), lane I L bicolor 81-306; lane 2, L bicolor 83-216 (uncut DNA); lane 3, $L$ bicolor 83-216; lane $4, L$ bicolor CRBF569; lane 5, L bicolor CRBF581. To the left a molecular mass scale as determined by the position of Hindll-cut $\lambda$ DNA standard. 

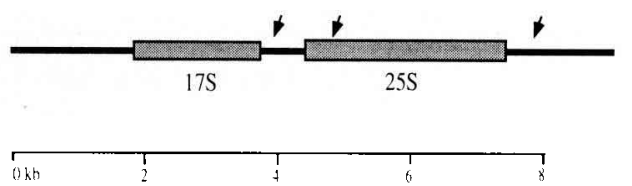

Fig 3. Organization of the rDNA repeat units in Coprinus cinereus showing one of the tandem repeats starting from the $3^{\prime}$ end of one $25 S$ gene, through the intergenic transcribed spacer (ITS), an $17 \mathrm{~S}$ gene, another intergenic spacer. EcoRl restriction sites are designated by arrowheads (after Cassidy et al, 1984).

most $L$ laccata isolates suggesting that there are 2 sets of the rDNA repeat which are similar, but have slight sequence divergence.

\section{DISCUSSION}

Morphological, physiological, and biochemical data have suggested that $L$ laccata and $L$ bicolor comprise subspecies. On the basis of the electrophoretic pattern of total proteins, large variations in polypeptide accumulation within Laccaria isolates have been distinguished (Hilbert and Martin, unpublished data). Previous studies, which compared RFLPs of rDNA genes from North American isolates of Laccaria demonstrated the usefulness of this approach, and rDNA gene restriction patterns have thus been proposed as a taxonomic aid and epidemiological marker for ectomycorrhizal fungi (Armstrong et al, 1989; Rogers et al, 1989; Gardes et al, 1990). Therefore, it was pertinent to evaluate whether such polymorphisms of RFLP patterns could be found for European isolates.

Using this method, species- or subspecies-specific cores of restriction fragments, homologous to Coprinus cinereus rDNA, have been observed. Among the restriction endonucleases tested, EcoRI provided a simple method to distinguish isolates of $L$ laccata and $L$ bicolor. When total DNA from isolates collected from various geographical locations was digested with Eco$\mathrm{RI}$ and subjected to gel electrophoresis and rDNA hybridization, a different fractionation pattern was associated with each species and most isolates within a species. Thus, species such as Laccaria species, usually considered as difficult to distinguish using phenotypic characteristics could be differentiated. Our results confirm that isolate $\mathrm{S} 238$ formerly accessioned and distributed as $L$ laccata belongs to $L$ bicolor, and support its recent reclassification (Armstrong et al, 1989).

Taken collectively, our work and that of Rogers et al (1989) and Armstrong et al (1989) demonstrates the evolutionary conservation and utility of ribosomal gene probes for identifying ectomycorrhizal fungi. Rogers et al (1989) and Armstrong et al (1989) isolated DNA using CTAB-based procedures, used the same $L$ laccata isolate (GM1774), and some of the same endonucleases, but hybridized the RFLPs with different ribosomal gene probes. The former used a non-specific plasmid probe from a non-filamentous fungus (pBD4: containing Saccharomyces cerevisiae ribosomal genes; Bell et al, 1977) and the later group hybridized RFLPs with the nonspecific ribosomal gene plasmid probe pCc1. The hybridized RFLPs for the EcoRI digest of isolate Gml1774 was identical for both probes (table II). In the present study, we hybridized RFLPs with pCc1 and used a SDS-DNA extraction method whereas Armstrong et al (1989) used a CTABbased DNA extraction method. Hybridized RFLPs of the EcoRI digest of $L$ bicolor S238 for both DNA extraction methods were identical, indicating the compatibility of results among DNA extraction methods. 
Table II. Hybridization fragment sizes of EcoRI-digested ribosomal DNA from Laccaria laccata and Laccaria bicolor isolates from various geographical locations in France and North America.

Fungal isolates

EcoR/ r DNA fragments $(k b)$

\begin{tabular}{|c|c|c|c|c|c|c|c|c|c|}
\hline Laccaria laccata S1023 & 1.45 & & 2.0 & & & 4.0 & & 8.0 & 9.4 \\
\hline L laccata \$106 & 1.45 & 1.7 & & & 3.8 & 4.0 & & 8.0 & 9.4 \\
\hline L laccata 003 & 1.45 & 1.7 & & & 3.8 & 4,0 & & 8.0 & 9.4 \\
\hline$L$ laccata Peyrat & 1.45 & & 2.0 & & 3.8 & 4.0 & & 8.0 & 9.4 \\
\hline L laccata 83-222 & 1.45 & 1.7 & & & 3.8 & & & 8.0 & 9.4 \\
\hline L laccata Cham3 & 1.45 & 1.7 & & & 3.8 & & & & 9.4 \\
\hline L laccata GM1774a & 1.45 & & 2.0 & 3.0 & & & 7.6 & & \\
\hline Laccaria bicolor $\mathrm{S} 238$ & 1.45 & & 2.0 & & & & & 8.0 & 9.4 \\
\hline L bicolor $5238^{b}$ & 1.45 & & 2.0 & & & 4.0 & & 8.0 & 9.4 \\
\hline L bicolor 81-306 & 1.45 & 1.7 & & & & & & & 9.4 \\
\hline L bicolor $83-216$ & 1.45 & 1.7 & & & & 4.0 & & & 9.4 \\
\hline L bicolor CRBF 569 & 1.45 & & 2.0 & & & & & 8.0 & 9.4 \\
\hline L bicolor CRBF 581 & 1.45 & & 2.0 & & & & & 8.0 & 9.4 \\
\hline $\begin{array}{l}L \text { bicolor MC: } \\
\text { 10/24/86-1 a }\end{array}$ & 1.45 & & 2.0 & 3.0 & & 7.2 & 7.9 & & \\
\hline
\end{tabular}

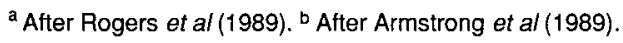

Our results strongly suggest that $E c o R !$ restriction digest patterns of total DNA provide a useful adjunct to other taxonomic criteria to distinguish isolates of the 2 economically important species $L$ laccata and $L$ bicolor. However, cost, technical skill required, and utilization of radioactive isotopes could prevent the spread of RFLPs in identifying ectomycorrhizal isolates. Polymerase chain reaction (PCR) is being widely used for efficient amplification of specific sequences of genomic DNA (Saiki et al, 1988; Gardes et al, 1991). Amplification of rDNA and gene restriction patterns of the amplified DNA from ectomycorrhizal fungi and ectomycorrhizas are now under study in our laboratories.

\section{REFERENCES}

Armstrong JL, Fowles NL, Rygiewicz PT (1989) Restriction fragment length polymorphisms distinguish ectomycorrhizal fungi. Plant Soil 116, 1-7

Cassidy JR, Moore D, Lu BC, Pukkila PJ (1984) Unusual organization and lack of recombination in the ribosomal genes of Coprinus cinereus. Curr Genet 8, 607-613

Bell BI, DeGennaro LJ, Gelfand DH, Bishop RJ, Valenzuela P, Rutter WJ (1977) Ribosomal RNA genes of Saccharomyces cerevisiae. $J$ Biol Chem 252, 8118-8125

Garber RC, Turgeon BG, Selker EU, Yoder OC (1988) Organization of ribosomal RNA genes in the fungus Cochliobolus heterostrophus. Curr Genet 14, 573-582 
Gardes M, Fortin JA, Mueller GM, Kropp BR (1990) Restriction fragment length polymorphisms in the nuclear ribosomal DNA of four Laccaria spp: $L$ bicolor, $L$ laccata, $L$ proxima, and $L$ amethystina. Phytopathology $80,1312-$ 1317

Gardes $M$, White TJ, Fortin JA, Bruns TD, Taylor JW (1991) Identification of indigenous and introduced symbotic fungi in ectomycorrhizae by amplification of nuclear and mitochondrial ribosomal DNA. Can J Bot 169, 180-190

Hintz WEA, Anderson JB, Horgen PA (1989) Relatedness of three species of Agaricus inferred from restriction fragment length polymorphism analysis of the ribosomal DNA repeat and mitochondrial DNA. Genome 32, 173-178

Klassen GR, McNabb SA, Dick MW (1987) Comparison of physical maps of ribosomal DNA repeating units in Pythium, Phytophthora and Apodachlya. J Gen Microbiol 133, 2953-2959

Klich MA, Mullaney EJ (1987) DNA restriction enzyme fragment polymorphism as a tool for rapid differentiation of Aspergillus flavus from Aspergillus oryzae. Exp Mycol 11, 170-175

Kropp BR, Fortin JA (1988) The incompatibility system and relative ectomycorrhizal performance of monokaryons and reconstituted dikaryons of Laccaria bicolor. Can J Bot 66, 289-294

Kropp BR, McAfee BJ, Fortin JA (1986) Variable loss of ectomycorrhizal ability in monokaryotic and dikaryotic cultures of Laccaria bicolor. Can J Bot 65, 500-504

Laaser G, Moller E, Jahnke KD, Bahnweg G, Prillinger $\mathrm{H}$, Prell $\mathrm{HH}$ (1989) Ribosomal DNA restriction fragment analysis as a taxonomic tool is separating physiologically similar basidiomycetous yeasts. System Appl Microbiol 11, 170-175

Le Tacon F, Garbaye J, Bouchard D, Chevalier G, Olivier JM, Guimberteau J, Poitou N, Frochot $H(1988)$ Field results from ectomycorthizal inoculation in France. In: Canadian Workshop on Mycorrhizae in Forestry (La- londe M, Piché Y, eds) CRBF, Fac For Géod, Université Laval, Quebec, 51-74

Maniatis T, Fritsch FE, Sambrook J (1982) Molecular Cloning: A Laboratory Manual. Cold Spring Harbor Laboratory, Cold Spring Harbor, NY, $545 \mathrm{pp}$

Martin F, Delaruelle C, Hilbert JL (1990) An improved ergosterol assay to estimate the fungal biomass in ectomycorrhizas. Mycol Res 94, 1059-1064

Mueller GM, Vellinga EC (1986) Taxonomic and nomenclature notes on Laccaria $\mathrm{B}$ and $\mathrm{Br}$, Laccaria amethystea, $L$ fraterna, $L$ laccata, $L$ pumila, and their synonyms. Persoonia 13, $27-43$

Reader U, Broda P (1984) Comparison of the lignin-degrading white rot fungi Phanerochaete chrysosporium and Sporotrichum pulverentum at the DNA level. Curr Genet 8, 499-506

Rogers SO, Rehner S, Bledsoe C, Mueller GJ, Ammirati JF (1989) Extraction of DNA from Basidiomycetes for ribosomal DNA hybridizations. Can J Bot 67, 1235-1243

Saiki RK, Gelfand DH, Stoffel S, Scharf SJ, Higuchi R, Horn GT, Mullis KB, Erlich HA (1988) Primer-directed enzymatic amplification of DNA with a thermostable DNA polymerase. Science 239, 487-491

Southern EM (1975) Detection of specific sequences among DNA fragments separated by gel electrophoresis. $J \mathrm{Mol} \mathrm{Biol} 98,503-$ 517

Specht CA, Novotny CP, Ullich RC (1984) Strain specific differences in ribosomal DNA from the fungus Schizophyllum commune. Curr Genet 8, 219-222

Wong KKY, Piché $Y$, Montpetit D, Kropp BR (1989) Differences in the colonization of Pinus banksiana roots by sib-monokaryotic and dikaryotic strains of ectomycorrhizal Laccaria bicolor. Can J Bot 67, 1717-1726

Wu MMJ, Cassidy JR, Pukkila PJ (1983) Polymorphisms in DNA of Coprinus cinereus. Curr Genet 7, 385-392 